\title{
Clinical cell therapy guidelines for neurorestoration (China version 2016)
}

This article was published in the following Dove Press journal:

Journal of Neurorestoratology

13 February 2017

Number of times this article has been viewed

\author{
Hongyun Huang' \\ Lin Chen ${ }^{2}$ \\ Qingyan Zou ${ }^{3}$ \\ Fabin $\mathrm{Han}^{4}$ \\ Tiansheng Sun ${ }^{5}$ \\ Gengsheng Mao' \\ Xijing $\mathrm{He}^{6}$
}

'Institute of Neurorestoratology, General Hospital of Armed Police

Forces, ${ }^{2}$ Department of Neurosurgery, Yuquan Hospital, Tsinghua University,

Beijing, ${ }^{3}$ Guangdong 999 Brain

Hospital, Guangzhou, ${ }^{4}$ Centre

for Stem Cells and Regenerative

Medicine, Affiliated Hospital

of Taishan Medical University,

Liaocheng, Shandong, ${ }^{5}$ Department of

Orthopedics, Beijing Army General

Hospital, Beijing, 'Second Department

of Orthopedics, The Second Affiliated

Hospital of Xi'an Jiaotong University,

Xi'an, People's Republic of China

On behalf of the Chinese Association of Neurorestoratology and Chinese

Branch of the International

Association of Neurorestoratology

Correspondence: Xijing He

Second Department of Orthopedics,

The Second Affiliated Hospital of Xi'an

jiaotong University, 157 West Road,

7I0004 Xi'an, Shaanxi, People's

Republic of China

Tel +86 I390926 6195

Email xijing_h@vip.tom.com

Hongyun Huang

Institute of Neurorestoratology, General

Hospital of Armed Police Forces, 100039

Beijing, People's Republic of China

Tel +86 I39 I0II 6608

Email hongyunh@gmail.com
Abstract: Cell therapy has been shown to be a key clinical therapeutic option for central nervous system disease or damage, and $>30$ types of cells have been identified through preclinical studies as having the capacity for neurorestoration. To standardize the clinical procedures of cell therapy as one of the strategies for treating neurological disorders, the first set of guidelines governing the clinical application of neurorestoration was completed in 2011 by the Chinese Branch of the International Association of Neurorestoratology. Given the rapidly advancing state of the field, the Neurorestoratology Professional Committee of Chinese Medical Doctor Association (Chinese Association of Neurorestoratology) and the Chinese Branch of the International Association of Neurorestoratology have approved the current version known as the "Clinical Cell Therapy Guidelines for Neurorestoration (China Version 2016)". We hope this guideline will reflect the most recent results demonstrated in preclinical research, transnational studies, and evidence-based clinical studies, as well as guide clinical practice in applying cell therapy for neurorestoration.

Keywords: cell therapy, neurorestoration, China, clinical application

\section{Introduction}

Neurorestoratology is an emerging discipline at the intersection of clinical medicine and neuroscience. Its goal is to restore, promote, and maintain the integrity of impaired or lost neuronal functions and/or structures. ${ }^{1}$

The "Beijing Declaration of IANR" (agreed upon at the International Association of Neurorestoratology [IANR] 2015 Conference in Tehran) declared as its fundamental tenet that "functional recovery is possible after central nervous system (CNS) injury and neurodegeneration" and noted that "cell therapies may become a key clinical therapeutic option for acute, subacute, and/or chronic CNS disease or damage". ${ }^{1}$ More than 30 types of cells have been identified through preclinical studies as having the capacity for neurorestoration..$^{2-62}$

Cells that have been tested to date in clinical neurorestorative treatments can be classified into the following three categories: 1) immature or mature neural functional or supporting cells, some of which are still able to proliferate (including neural progenitor or precursor cells, olfactory ensheathing cells, Schwann cells, oligodendrocytes, and neurons); 2) stromal cells (including bone marrow, umbilical cord or peripheral blood mononuclear cells, umbilical cord stromal cells, and adipose stromal cells); 3) totipotent, pluripotent, multipotent, or unipotent stem cells, which include embryonic stem cells, induced pluripotential cells, and adult stem cells. ${ }^{63-67}$

The guidelines presented in this document are intended for clinical applications utilizing cells in the first two categories described earlier. To date, clinical trials and 
treatments based on the first and second categories of cells have been established in $>30$ countries. Clinical studies have documented the safety and efficacy of treatments based on the first two categories of cells, with many demonstrating neurological function improvement for patients. ${ }^{68-107}$ Because of concerns over tumorigenicity and the difficulties in controlling the cellular differentiation process, clinical applications of the third category of cells require additional scrutiny and thus fall outside the scope of this current set of guidelines. We recommend that any clinical studies utilizing the cells from the third category should strictly comply with the following draft regulations issued by the Science and Educational Division of the National Health and Family Planning Commission of China (NHFPC): "Stem cell quality control and pre-clinical research guideline principles (Trial) (Document 2015 No.46)" and "Stem cell clinical research management measures (Trial) (Document 2015 No.48)".

The first set of guidelines governing the clinical application of neurorestoration, "Chinese clinical standard of neurorestorative cell therapy", was formulated in 2011 by the Chinese Branch of the International Association of Neurorestoratology. ${ }^{108}$ These guidelines were revised, translated into English, and published in 2012. ${ }^{109}$ The guidelines were further revised as "Chinese clinical application guideline of neurorestorative cell therapy (2015 version)". ${ }^{110}$ These guidelines have played a significant role in standardizing treatment protocols and setting up an international set of professional standards agreed upon by leading experts in this emerging field. Given the rapidly advancing state of the field, the Neurorestoratology Professional Committee of Chinese Medical Doctor Association (Chinese Association of Neurorestoratology) and the Chinese Branch of the International Association of Neurorestoratology have jointly collaborated to amend and update the existing guidelines to reflect the most recent results demonstrated in preclinical research, transnational studies, and evidence-based clinical studies. The current version, known as the "Clinical Cell Therapy Guidelines for Neurorestoration (2016)", was approved by the executive boards of the Chinese Association of Neurorestoratology and the Chinese Branch of the International Association of Neurorestoratology on June 18, 2016.

\section{Recommended standards for personnel and institutions conducting cell therapies in China Equipment}

Personnel and institutions conducting cell therapies in China must have laboratory facilities and equipment that comply with the relevant national standards for ensuring cell quality control.

\section{Personnel}

\section{Clinical personnel}

Physicians performing cell transplantation procedures should have acquired relevant professional training and certification required to ensure high-level competency in this field. Supervising clinicians should have attained a rank of associate chief physician or above. They should have also passed all certification examinations recommended by the relevant professional societies or associations.

\section{Laboratory personnel}

Directors of cell preparation laboratories should have attained at least a master's degree in a relevant scientific field and have achieved a high professional rank; technicians involved in cell preparation should have undergone all relevant professional training and passed all certification examinations in cell preparation recommended by the relevant professional societies or associations.

\section{Oversight personnel}

Inspectors assessing cell quality should have attained at least a bachelor's degree in a relevant scientific field, undergone all relevant professional training, and passed all certification examinations in cell preparation recommended by the relevant professional societies or associations.

\section{Institutional board of reviewing}

All clinical studies or treatment conducting cell therapies and involving human participants should be reviewed and approved by the institutional board of ethics committee.

The Chinese Association of Neurorestoratology is responsible for offering professional training and establishing standardized assessment and credentialing procedures to ensure the integrity and quality of neurorestorative cell therapy procedures conducted in China.

\section{Provisions}

This revised set of guidelines includes the following set of provisions: guiding principles of neurorestorative cell therapy, the cell types governed by these guidelines, cell quality control procedures, cell dosages, informed consent procedures for patients and other participants, indications for undergoing cell therapy, contraindication for undergoing cell therapy, operating procedures (including surgical procedures 
and key points for cellular injection), and recommendations for evaluating safety and efficacy.

\section{Guiding principles of the neurorestorative cell therapy}

The guiding principles for the neurorestorative cell therapy are timeliness, adequate dosage, multiple routes, multiple cell types, multiple courses, and combined treatment. The optimization of personalized treatment should be highlighted and explored more by precise mechanism.

\section{Cell type nomenclature}

Cells are the basic unit of structure and function of organisms, including all the various stages of development and various cellular functions. From the cell development period, the cells can be divided into stem cells and premature (immature) or mature functional cells. The stem cells include totipotent, pluripotent, multipotent, or unipotent stem cells. The premature (immature) or mature functional cells include the neural progenitor or precursor cells, olfactory ensheathing cells, Schwann cells, oligodendrocytes, neurons, mesenchymal or stromal cells, and so on. The difference between the stem cells and progenitor cells is that the former can proliferate without limitation and the latter can proliferate with limitation and only differentiate into special kinds of the cells or target cells. Stem cells are one of the most important cell lines. Defining the concept of stem cells or replacing the term of cells by stem cells, has risked using stem cells in cell therapy. Therefore, the description of cell therapy should strictly normalize the cell type nomenclature.

We suggest that each cell type should be named after its derived source, such as the olfactory ensheathing cells derived from olfactory mucosa, the Schwann-like cells derived from sciatic nerve, the progenitor/precursor cells derived from brain, the olfactory ensheathing cells derived from olfactory bulb, the mononuclear cells derived from bone marrow, the peripheral blood, or umbilical cord blood, and the stromal or mesenchymal cells derived from the adipose tissue or umbilical cord.

\section{Cell quality control}

Quality control is the basis of the cell therapeutic safety and efficacy. The whole process includes the cell collecting, culturing, identifying, amplifying, detecting composition and the content of various cytokines, transmission, and passage number, adding exogenous factors, cell storing, testing biological effects (dynamics proliferation), cell transporting, managing before clinical use, operating procedure of cell transplantation or therapy, and etc. Serum-free cultures are recommended; otherwise, the fetal bovine sera should be washed or removed. The standard of the quality control should include at least the following: the total number of cells, the passage number in vitro, cell purity, cell viability (at least $95 \%$ ), biological effects (at least $80 \%$ ), the proportion of special surface markers, and the detection of infectious disease and endotoxin. In certain low-temperature conditions, the optimal time from the clinical laboratory to transplantation of cells to the patient should not exceed $>2$ hours. ${ }^{11}$

\section{Cell dosage}

Cells must be used at an effective dose. With more clinical treatment studies, the cell dosage will be more accurate. Currently, we recommend that the maximum injection volume of cell suspension will not exceed $200 \mu \mathrm{L}$ for the brain parenchyma, ${ }^{73,112-114} 25 \mu \mathrm{L}$ for the spinal cord parenchyma, ${ }^{68,69,115} 10 \mathrm{~mL}$ by the cerebrospinal fluid route, ${ }^{116}$ and $10-100 \mathrm{~mL}$ by vascularity. ${ }^{114,117-121}$

The current recommendation of the prescription for the commonly used single dose of cells is as below:

1. Glial cells, such as olfactory ensheathing cells and Schwann cells, $(2.0-3.0) \times 10^{6}$ for the intrathecal injection; $(1.0-2.0) \times 10^{6}$ for the spinal cord injection; and $(2.0-4.0) \times 10^{6}$ for the brain parenchymal injection. ${ }^{68,69,73,14,122}$

2. Neural progenitor/precursor cells: $(5.0-6.0) \times 10^{6}$ for the intrathecal injection; $(5.0-6.0) \times 10^{6}$ for the spinal cord injection; and $\left(1.0 \times 10^{7}\right)$ for the brain parenchymal injection. ${ }^{114,119,123}$

3. Mesenchymal or stromal cells derived from umbilical cord: $(0.5-0.8) \times 10^{6} / \mathrm{kg}$ body weight for intravenous infusion (the elderly and frail patients should reduce to $1 / 3$ to $1 / 2$ dosage); (5.0-8.0) $\times 10^{6}$ for the intrathecal injection; and $1.0 \times 10^{7}$ for the brain parenchymal injection. ${ }^{73,124-130}$

4. Mononuclear cells derived from cord blood: $(1.0-2.0) \times 10^{6} / \mathrm{kg}$ body weight for intravenous infusion, the elderly and frail patients should reduce to $1 / 3-1 / 2$ dosage; and (5.0-6.0) $\times 10^{6}$ for the intrathecal injection. ${ }^{75,81,84,88}$

5. Mononuclear cells derived from bone marrow: $(3.0-9.0) \times 10^{8}$ for intravenous infusion and $(5.0-6.0) \times 10^{6}$ for the intrathecal injection. ${ }^{78,80,117,118,120,121}$

\section{Patient informed consent}

Patients and their families have the right to know about all the possible benefits and potential risks of matters related with the cell transplantation and procedures. Physicians should continue to learn and master the latest cell therapy-related knowledge in order to give objective answers and explanation. 
All participants should fill and sign a consent form before the clinical study or treatment is performed.

\section{Indications for undergoing cell therapy}

Neurological system diseases and damages, which include the neurotrauma, neurodegeneration, ischemic/hypoxic brain injury, demyelination, sensory motor disorders, neuropathic pain, as well as nerve damage caused by intoxication, physical/chemical factors, immune, infectious, inflammatory, hereditary, congenital, developmental factors, etc.

\section{Contraindications for undergoing cell therapy}

Patients with poor general condition or major organ dysfunction cannot tolerate cell therapy procedures. There are the infections or pressure sores in the surgical site, bleeding tendency, coagulation disorder that cannot be corrected, and emotional disturbance. Patients with hypersensitivity, $>90$ years old, or pregnant are not recommended for the procedure.

\section{Operating record and key points}

The operating record of the cell therapy methods includes anesthesia methods, transplanting approach, surgical procedure, transplanting method, transplanting site, transplanted cell type, quantity of transplanted cells, and the concentration and volume.

Examples for the therapeutic methods are described below:

1. Stereotactic brain parenchyma $(\times$ target $)$ neural progenitor/precursor cell transplantation through the frontal approach under local anesthesia.

2. $\times x$ cell transplantation through ventricle puncture under local anesthesia.

3. $x \times$ cell transplantation by cisterna magna puncture under local anesthesia.

4. Intrathecal $\times \times$ cell transplantation through cervical, thoracic, or lumbar puncture under local anesthesia.

5. Subarachnoid $\times \times$ cell transplantation in cervical, thoracic, or lumbar puncture under local anesthesia by X-ray guidance.

6. Spinal cord parenchyma $\times \times$ cell transplantation in cervical, thoracic, or lumbar puncture under general anesthesia.

7. Myelography computed tomography (CT)-guided spinal cord parenchyma $\times \times$ cell transplantation in cervical, thoracic, or lumbar puncture under local anesthesia.
8. Myelography CT-guided spinal subarachnoid $\times \times$ cell transplantation in cervical, thoracic, or lumbar puncture under local anesthesia.

9. CT-guided spinal cord parenchyma $\times \times$ cell transplantation in cervical, thoracic, or lumbar puncture under local anesthesia.

10. CT-guided spinal subarachnoid $\times \times$ cell transplantation in cervical, thoracic, or lumbar puncture under local anesthesia.

11. Intravenous $\times \times$ cell transplantation.

$12 . \times \times$ cell intravascular transplantation by ultra-artery catheterization.

13. Intramuscular $\times \times$ cell transplantation.

Each different kind of cells should have the best route for the most therapeutic effect. The therapeutic effect depends mainly on the different route for each different cell type. With more preclinical and clinical treatment studies, the best therapeutic route with the most effect and safety may be found in the future. Current first options of operating key points are suggested as below according to a series of clinical and basic studies. ${ }^{68,69,73,114,124-126,131-134}$

In brain local disorders (brain injury or stroke) cells should be injected into the edge of lesion. In non-special or diffuse disorders (cerebral palsy, amyotrophic lateral sclerosis) cells should be injected into "the key point for neural network restoration (KPNNR)". Its anatomic structure locates at anterior $1 / 4-1 / 3$ of the lateral ventricle and 23-27 mm away from the midline, where the pyramidal tract in frontal corona radiate through and represents a point at which numerous projection fibers, association fibers, and commissural fibers converge.

In spinal cord disorders cells should be injected into the spinal cord below and above the junction of normal and damaged tissue.

In peripheral nerve disorders cells should be injected into the lesion site.

\section{Safety evaluation}

Detailed records must be kept for the cell therapy-related adverse events by using standardized terminology, such as fever, headache, nausea, vomiting, anorexia, infection, rash, poor wound healing, dyspnea, increased/decreased blood pressure, increased/decreased heart rate, neurological deterioration, cerebrospinal fluid leakage, twitch, and so on.

\section{Efficacy evaluation}

Uniform evaluation standards or scales are currently used in the national community to assess the patients' functions for 
different diseases (referring Neurorestoratology ${ }^{133}$ or CNS Neurorestoratology ${ }^{134}$ ). Chinese Association of Neurorestoratology regularly decides the national training courses for the physicians to assess patients. They should be trained with the uniform evaluation, pass the examination, and acquire professional certification.

\section{Policy of further treatment and data collection}

The active exploration of individual treatments must be based on the clinical standard cell therapy for continually improving efficacy. It is recommended to accurately collect the patients' information that includes brain functional magnetic resonance imaging (MRI), brain or spinal cord MRI-diffusion tensor imaging, peripheral magnetic resonance angiography, and the electrical physiological examination.

\section{Basic principle of cell therapy}

According to the previous data from clinical practice, ${ }^{73,100,119,124-126,133-135}$ the combination of different cells, combined transplanting approaches, setting treatment course, and comprehensive strategies are the current main study direction. The Chinese Association of Neurorestoratology will revise and release the program of safety and better efficacy in future and actively organize multicenter studies for different diseases. Randomized, double-blind, controlled clinical studies should be carried out preferentially; if unsuitable, other types of clinical studies or trials should be started.

\section{Publishing duty}

All groups that carry out the clinical cell therapy should promptly analyze, summarize, and share their data for publications to other physicians as reference, for further evaluation and validation.

\section{Disclosure}

The authors report no conflicts of interest in this work.

\section{References}

1. Young W, AlZoubi Z, Saberi H, et al. Beijing declaration of international association of neurorestoratology (IANR). J Neurorestoratol. 2015;3:121-122.

2. Döbrössy M, Busse M, Piroth T, Rosser A, Dunnett S, Nikkhah G. Neurorehabilitation with neural transplantation. Neurorehabil Neural Repair. 2010;24(8):692-701.

3. Ghanizadeh A. Non-neuronal cell transplantation as a possible therapeutic approach for epilepsy treatment. Brain Res Bull. 2010;83(5):194-195.

4. Waldau B, Hattiangady B, Kuruba R, Shetty AK. Medial ganglionic eminence-derived neural stem cell grafts ease spontaneous seizures and restore GDNF expression in a rat model of chronic temporal lobe epilepsy. Stem Cells. 2010;28(7):1153-1164.
5. Huang H, Chen L, Sanberg P. Cell therapy from bench to bedside translation in CNS neurorestoratology era. Cell Med. Part B Cell Transplant. 2010;1(1):15-46.

6. Choi JH, Chung JY, Yoo DY, et al. Cell proliferation and neuroblast differentiation in the rat dentate gyrus after intrathecal treatment with adipose-derived mesenchymal stem cells. Cell Mol Neurobiol. 2011;31(8):1271-1280.

7. Lopatina T, Kalinina N, Karagyaur M, et al. Adipose-derived stem cells stimulate regeneration of peripheral nerves: BDNF secreted by these cells promotes nerve healing and axon growth de novo. PLoS One. 2011;6(3):e17899.

8. Ikegame Y, Yamashita K, Hayashi S, et al. Comparison of mesenchymal stem cells from adipose tissue and bone marrow for ischemic stroke therapy. Cytotherapy. 2011;13(6):675-685.

9. Yang YC, Liu BS, Shen CC, Lin CH, Chiao MT, Cheng HC. Transplantation of adipose tissue-derived stem cells for treatment of focal cerebral ischemia. Curr Neurovasc Res. 2011;8(1):1-13.

10. Yalvac ME, Rizvanov AA, Kilic E, et al. Potential role of dental stem cells in the cellular therapy of cerebral ischemia. Curr Pharm Des. 2009;15(33):3908-3916.

11. Dell'Anno MT, Caiazzo M, Leo D, et al. Remote control of induced dopaminergic neurons in parkinsonian rats. J Clin Invest. 2014;124(7):3215-3229.

12. Dyson SC, Barker RA. Cell-based therapies for Parkinson's disease. Expert Rev Neurother. 2011;11(6):831-844.

13. Lasala GP, Minguell JJ. Vascular disease and stem cell therapies. Br Med Bull. 2011;98:187-197.

14. Rhee YH, Ko JY, Chang MY, et al. Protein-based human iPS cells efficiently generate functional dopamine neurons and can treat a rat model of Parkinson disease. J Clin Invest. 2011;121(6):2326-2335.

15. Hunt CJ. Cryopreservation of human stem cells for clinical application: a review. Transfus Med Hemother. 2011;38(2):107-123.

16. Zhang Y, Wang D, Chen M, Yang B, Zhang F, Cao K. Intramyocardial transplantation of undifferentiated rat induced pluripotent stem cells causes tumorigenesis in the heart. PLoS One. 2011;6(4):e19012.

17. Tomaskovic-Crook E, Crook JM. Human embryonic stem cell therapies for neurodegenerative diseases. CNS Neurol Disord Drug Targets. 2011;10(4):440-448.

18. Hernándeza J, Torres-Espína A, Navarro X. Adult stem cell transplants for spinal cord injury repair: current state in preclinical research. Curr Stem Cell Res Ther. 2011;6(3):273-287.

19. Loewenbrück K, Storch A. Stem cell-based therapies in Parkinson's disease: future hope or current treatment option? J Neurol. 2011;258(suppl 2):S346-S353.

20. Lunn JS, Sakowski SA, Federici T, Glass JD, Boulis NM, Feldman EL. Stem cell technology for the study and treatment of motor neuron diseases. Regen Med. 2011;6(2):201-213.

21. Hilfiker A, Kasper C, Hass R, Haverich A. Mesenchymal stem cells and progenitor cells in connective tissue engineering and regenerative medicine: is there a future for transplantation? Langenbecks Arch Surg. 2011;396(4):489-497.

22. Gaspard N, Vanderhaeghen P. From stem cells to neural networks: recent advances and perspectives for neurodevelopmental disorders. Dev Med Child Neurol. 2011;53(1):13-17.

23. Pellegrini KL, Beilharz MW. The survival of myoblasts after intramuscular transplantation is improved when fewer cells are injected. Transplantation. 2011;91(5):522-526.

24. Chang YK, Chen MH, Chiang YH, et al. Mesenchymal stem cell transplantation ameliorates motor function deterioration of spinocerebellar ataxia by rescuing cerebellar Purkinje cells. J Biomed Sci. 2011;18(1):54.

25. Yalvaç ME, Yarat A, Mercan D, Rizvanov AA, Palotás A, Şahin F. Characterization of the secretome of human tooth germ stem cells (hTGSCs) reveals neuro-protection by fine-tuning micro-environment. Brain Behav Immun. 2013;32:122-130.

26. Amoh Y, Li L, Katsuoka K, Hoffman RM. Multipotent hair follicle stem cells promote repair of spinal cord injury and recovery of walking function. Cell Cycle. 2008;7(12):1865-1869. 
27. Lee JM, Bae JS, Jin HK. Intracerebellar transplantation of neural stem cells into mice with neurodegeneration improves neuronal networks with functional synaptic transmission. J Vet Med Sci. 2010;72(8):999-1009.

28. Sotelo C, Alvarado-Mallart RM. Reconstruction of the defective cerebellar circuitry in adult Purkinje cell degeneration mutant mice by Purkinje cell replacement through transplantation of solid embryonic implants. Neuroscience. 1987;20(1):1-22.

29. Novikova LN, Lobov S, Wiberg M, Novikov LN. Efficacy of olfactory ensheathing cells to support regeneration after spinal cord injury is influenced by method of culture preparation. Exp Neurol. 2011;229(1):132-142.

30. Su L, Xu J, Ji BX, et al. Autologous peripheral blood stem cell transplantation for severe multiple sclerosis. Int J Hematol. 2006; 84(3):276-281.

31. Yarygin KN, Kholodenko IV, Konieva AA, et al. Mechanisms of positive effects of transplantation of human placental mesenchymal stem cells on recovery of rats after experimental ischemic stroke. Bull Exp Biol Med. 2009;148(6):862-868.

32. Loftis JM. Sertoli cell therapy: a novel possible treatment strategy for treatment-resistant major depressive disorder. Med Hypotheses. 2011;77(1):35-42.

33. Caiazzo M, Dell'anno MT, Dvoretskova E, et al. Direct generation of functional dopaminergic neurons from mouse and human fibroblasts. Nature. 2011;476(7359):224-227.

34. Xu X, Geremia N, Bao F, Pniak A, Rossoni M, Brown A. Schwann cell co-culture improves the therapeutic effect of bone marrow stromal cells on recovery in spinal cord-injured mice. Cell Transplant. 2010;20(7):1065-1086.

35. Schwartz M. "Tissue-repairing" blood-derived macrophages are essential for healing of the injured spinal cord: from skin-activated macrophages to infiltrating blood-derived cells? Brain Behav Immun. 2010;24(7):1054-1057.

36. Vaquero J, Zurita M. Functional recovery after severe CNS trauma: current perspectives for cell therapy with bone marrow stromal cells. Prog Neurobiol. 2010;93(3):341-349.

37. Roshal LM, Tzyb AF, Pavlova LN, et al. Effect of cell therapy on recovery of cognitive functions in rats during the delayed period after brain injury. Bull Exp Biol Med. 2009;148(1):140-147.

38. Lin YC, Ko TL, Shih YH, et al. Human umbilical mesenchymal stem cells promote recovery after ischemic stroke. Stroke. 2011;42(7):2045-2053.

39. Chehrehasa F, Windus LC, Ekberg JA, et al. Olfactory glia enhance neonatal axon regeneration. Mol Cell Neurosci. 2010;45(3):277-288.

40. Bonner JF, Connors TM, Silverman WF, Kowalski DP, Lemay MA, Fischer I. Grafted neural progenitors integrate and restore synaptic connectivity across the injured spinal cord. $J$ Neurosci. 2011;31(12): 4675-4686.

41. Nagai N, Kawao N, Okada K, et al. Systemic transplantation of embryonic stem cells accelerates brain lesion decrease and angiogenesis. Neuroreport. 2010;21(8):575-579.

42. Ronaghi M, Erceg S, Moreno-Manzano V, Stojkovic M. Challenges of stem cell therapy for spinal cord injury: human embryonic stem cells, endogenous neural stem cells, or induced pluripotent stem cells? Stem Cells. 2010;28(1):93-99.

43. Salehi M, Pasbakhsh P, Soleimani M, et al. Repair of spinal cord injury by co-transplantation of embryonic stem cell-derived motor neuron and olfactory ensheathing cell. Iran Biomed J. 2009;13(3):125-135.

44. Park BW, Kang DH, Kang EJ, et al. Peripheral nerve regeneration using autologous porcine skin-derived mesenchymal stem cells. J Tissue Eng Regen Med. 2012;6(2):113-124.

45. Rosenkranz K, Meier C. Umbilical cord blood cell transplantation after brain ischemia-From recovery of function to cellular mechanisms. Ann Anat. 2011;193(4):371-379.

46. Xiong N, Cao X, Zhang Z, et al. Long-term efficacy and safety of human umbilical cord mesenchymal stromal cells in rotenoneinduced hemiparkinsonian rats. J Tissue Eng Regen Med. 2012;6(2): 113-124.
47. Dongmei H, Jing L, Mei X, et al. Clinical analysis of the treatment of spinocerebellar ataxia and multiple system atrophy-cerebellar type with umbilical cord mesenchymal stromal cells. Cytotherapy. 2011;13(8):913-917.

48. Wang Y, Piao JH, Larsen EC, Kondo Y, Duncan ID. Migration and remyelination by oligodendrocyte progenitor cells transplanted adjacent to focal areas of spinal cord inflammation. J Neurosci Res. 2011;89(11):1737-1746.

49. Xu XX, Shao XM, Yu F, Liu LM, Zhang MX, Gao XL. Effects of tanycytes transplantation on the motor function score and rubrospinal motor evoked potentials of adult rats after spinal cord completely transected. Zhongguo Ying Yong Sheng Li Xue Za Zhi. 2010;26(4):433-435.

50. Michel-Monigadon D, Brachet P, Neveu I, Naveilhan P. Immunoregulatory properties of neural stem cells. Immunotherapy. 2011; 3(4 suppl):39-41.

51. Obenaus A, Dilmac N, Tone B, et al. Long-term magnetic resonance imaging of stem cells in neonatal ischemic injury. Ann Neurol. 2011;69(2):282-291.

52. Eaton MJ, Widerström-Noga E, Wolfe SQ. Subarachnoid transplant of the human neuronal hNT2.19 serotonergic cell line attenuates behavioral hypersensitivity without affecting motor dysfunction after severe contusive spinal cord injury. Neurol Res Int. 2011;2011:891605.

53. Minnerup J, Kim JB, Schmidt A, et al. Effects of neural progenitor cells on sensorimotor recovery and endogenous repair mechanisms after photothrombotic stroke. Stroke. 2011;42(6):1757-1763.

54. Wang R, Zhang J, Guo Z, et al. In-vivo PET imaging of implanted human retinal pigment epithelium cells in a Parkinson's disease rat model. Nucl Med Commun. 2008;29(5):455-461.

55. Narantuya D, Nagai A, Sheikh AM, et al. Microglia transplantation attenuates white matter injury in rat chronic ischemia model via matrix metalloproteinase-2 inhibition. Brain Res. 2010;1316:145-152.

56. Davies SJ, Shih CH, Noble M, Mayer-Proschel M, Davies JE, Proschel C. Transplantation of specific human astrocytes promotes functional recovery after spinal cord injury. PLoS One. 2011;6(3):e17328.

57. Yang X, Song L, Wu N, Liu Z, Xue S, Hui G. An experimental study on intracerebroventricular transplantation of human amniotic epithelial cells in a rat model of Parkinson's disease. Neurol Res. 2010; 32(10):1054-1059.

58. Cipriani S, Bonini D, Marchina E, et al. Mesenchymal cells from human amniotic fluid survive and migrate after transplantation into adult rat brain. Cell Biol Int. 2007;31(8):845-850.

59. Huang H, Chen L. Questions and discussion of clinical cell therapy in neurorestoratology. Chin J Cell Stem Cell. 2012;2:154-159.

60. Huang H, Mao G, Chen L, Liu A. Progress and challenges with clinical cell therapy in neurorestoratology. J Neurorestoratol. 2015;3:91-95.

61. Buzanska L, Jurga M, Stachowiak EK, Stachowiak MK, Domanska-Janik K. Neural stem-like cell line derived from a nonhematopoietic population of human umbilical cord blood. Stem Cells Dev. 2006;15(3):391-406.

62. Janowski M, Lukomska B, Domanska-Janik K. Migratory capabilities of human umbilical cord blood-derived neural stem cells (HUCB-NSC) in vitro. Acta Neurobiol Exp. 2011;71(1):24-35.

63. Vertès A. 2010 world stem cell summit - part 2. IDrugs. 2010;13(12): $822-824$.

64. Schwarz SC, Schwarz J. Translation of stem cell therapy for neurological diseases. Transl Res. 2010;156(3):155-160.

65. Baker M. Stem-cell pioneer bows out. Nature. 2011;479(7374):459.

66. Reardon S, Cyranoski D. Japan stem-cell trial stirs envy. Nature. 2014;513(7518):287-288.

67. Brown SA, Levi B, Lequeux C, Wong VW, Mojallal A, Longaker MT. Basic science review on adipose tissue for clinicians. Plast Reconstr Surg. 2010;126(6):1936-1946.

68. Huang HY, Chen L, Wang HM, et al. Influence of patients' age on functional recovery after transplantation of olfactory ensheathing cells into injured spinal cord injury. Chin Med J. 2003;116(10):1488-1491.

69. Huang H, Chen L, Xi H, et al. Fetal olfactory ensheathing cells transplantation in amyotrophic lateral sclerosis patients: a controlled pilot study. Clin Transplant. 2008;22(6):710-718. 
70. Raisman G, Carlstedt T, Choi D, Li Y. Clinical prospects for transplantation of OECs in the repair of brachial and lumbosacral plexus injuries: opening a door. Exp Neurol. 2011;229(1):168-173.

71. Lima C, Escada P, Pratas-Vital J, et al. Olfactory mucosal autografts and rehabilitation for chronic traumatic spinal cord injury. Neurorehabil Neural Repair. 2010;24(1):10-22.

72. Mackay-Sim A, Féron F, Cochrane J, et al. Autologous olfactory ensheathing cell transplantation in human paraplegia: a 3-year clinical trial. Brain. 2008;131(pt 9):2376-2386.

73. Chen L, Huang $\mathrm{H}, \mathrm{Xi} \mathrm{H}$, et al. Intracranial transplant of olfactory ensheathing cells in children and adolescents with cerebral palsy: a randomized controlled clinical trial. Cell Transplant. 2010;19(2):185-191.

74. Mizuno H. Adipose-derived stem and stromal cells for cell-based therapy: current status of preclinical studies and clinical trials. Curr Opin Mol Ther. 2010;12(4):442-449.

75. Sanberg PR, Eve DJ, Willing AE, et al. The treatment of neurodegenerative disorders using umbilical cord blood and menstrual blood-derived stem cells. Cell Transplant. 2011;20(1):85-94.

76. Richardson RM, Freed CR, Shimamoto SA, Starr PA. Pallidal neuronal discharge in Parkinson's disease following intraputamenal fetal mesencephalic allograft. J Neurol Neurosurg Psychiatry. 2011;82(3):266-271.

77. Mendez I, Dagher A, Hong M, et al. Simultaneous intrastriatal and intranigral fetal dopaminergic grafts in patients with Parkinson disease: a pilot study. Report of three cases. J Neurosurg. 2002;96(3):589-596.

78. Liao GP, Harting MT, Hetz RA, et al. Autologous bone marrow mononuclear cells reduce therapeutic intensity for severe traumatic brain injury in children. Pediatr Crit Care Med. 2015;16(3):245-255.

79. Walker PA, Harting MT, Shah SK, et al. Progenitor cell therapy for the treatment of central nervous system injury: a review of the state of current clinical trials. Stem Cells Int. 2010;2010:369578.

80. Karussis D, Karageorgiou C, Vaknin-Dembinsky A, et al. Safety and immunological effects of mesenchymal stem cell transplantation in patients with multiple sclerosis and amyotrophic lateral sclerosis. Arch Neurol. 2010;67(10):1187-1194.

81. Attar A, Ayten M, Ozdemir M, et al. An attempt to treat patients who have injured spinal cords with intralesional implantation of concentrated autologous bone marrow cells. Cytotherapy. 2011;13(1):54-60.

82. Freedman MS, Bar-Or A, Atkins HL, et al. The therapeutic potential of mesenchymal stem cell transplantation as a treatment for multiple sclerosis: consensus report of the International MSCT Study Group. Mult Scler. 2010;16(4):503-510.

83. Forthofer M, Wirth ED 3rd. Coordination of a neural tissue transplantation study in patients with posttraumatic syringomyelia. SCI Nurs 2001;18(1):19-29.

84. Yang WZ, Zhang Y, Wu F, et al. Human umbilical cord blood-derived mononuclear cell transplantation: case series of 30 subjects with hereditary ataxia. J Transl Med. 2011;9:65.

85. López-Lozano JJ, Bravo G, Brera B, et al. Long-term follow-up in 10 Parkinson's disease patients subjected to fetal brain grafting into a cavity in the caudate nucleus: the Clinica Puerta de Hierro experience. CPH Neural Transplantation Group. Transplant Proc. 1995;27(1):1395-1400.

86. Appel SH, Engelhardt JI, Henkel JS, et al. Hematopoietic stem cell transplantation in patients with sporadic amyotrophic lateral sclerosis. Neurology. 2008;71(17):1326-1334.

87. Sharma A, Gokulchandran N, Sane H, et al. Detailed analysis of the clinical effects of cell therapy for thoracolumbar spinal cord injury: an original study. J Neurorestoratol. 2013;1:13-22.

88. Gong D, Yu H, Wang W, Yang H, Han F. Human umbilical cord blood mononuclear cell transplantation for delayed encephalopathy after carbon monoxide intoxication. J Neurorestoratol. 2013;1:23-29.

89. Sych N, Klunnik M, Ivankova O, et al. Efficacy of fetal stem cells in Duchenne muscular dystrophy therapy. J Neurorestoratol. 2014;2:37-46.

90. Tsolaki M, Zygouris S, Tsoutsikas V, Anestakis D, Koliakos G. Treatment with adipose stem cells in a patient with moderate Alzheimer's disease: case report. J Neurorestoratol. 2015;3:115-120.
91. Huang H, Sun T, Chen L, et al. Consensus of clinical neurorestorative progress in patients with complete chronic spinal cord injury. Cell Transplant. 2014;23(suppl 1):S5-S17.

92. Qiao L, Huang H, Muresanu DF. Clinical neurorestorative progress in Alzheimer's disease. J Neurorestoratol. 2015;3:1-9.

93. Huang H, Chen L, Huang H. Clinical neurorestorative progress in traumatic brain injury. J Neurorestoratol. 2015;3:57-62.

94. Qiao L, Lu J, Huang H. Clinical neurorestorative progress in stroke. J Neurorestoratol. 2015;3:63-71.

95. Geng TC, Mark VW. Clinical neurorestorative progress in multiple sclerosis. J Neurorestoratol. 2015;3:83-90.

96. Chen L, Huang H, Duan WM, Mao GS. Clinical neurorestorative progress in Parkinson's disease. J Neurorestoratol. 2015;3:101-107.

97. Chen L, Huang H, Xi H, Mao G. Clinical neurorestorative progress in amyotrophic lateral sclerosis. J Neurorestoratol. 2015;3:109-114.

98. Moviglia GA, Varela G, Brizuela JA, et al. Case report on the clinical results of a combined cellular therapy for chronic spinal cord injured patients. Spinal Cord. 2009;47(6):499-503.

99. Moviglia GA, Moviglia-Brandolino MT, Varela GS, et al. Feasibility, safety, and preliminary proof of principles of autologous neural stem cell treatment combined with T-cell vaccination for ALS patients. Cell Transplant. 2012;21(suppl 1):S57-S63.

100. Huang H, Xi H, Chen L, Zhang F, Liu Y. Long-term outcome of olfactory ensheathing cell therapy for patients with complete chronic spinal cord injury. Cell Transplant. 2012;21(suppl 1):S23-S31.

101. Tabakow P, Jarmundowicz W, Czapiga B, et al. Transplantation of autologous olfactory ensheathing cells in complete human spinal cord injury. Cell Transplant. 2013;22(9):1591-1612.

102. Tabakow P, Raisman G, Fortuna W, et al. Functional regeneration of supraspinal connections in a patient with transected spinal cord following transplantation of bulbar olfactory ensheathing cells with peripheral nerve bridging. Cell Transplant. 2014;23(12):1631-1655.

103. Riley J, Glass J, Feldman EL, et al. Intraspinal stem cell transplantation in ALS: a phase I trial, cervical microinjection and final surgical safety outcomes. Neurosurgery. 2012;71(2):405-416.

104. Feldman EL, Boulis NM, Hur J, et al. Intraspinal neural stem cell transplantation in amyotrophic lateral sclerosis: phase 1 trial outcomes. Ann Neurol. 2014;75(3):363-373.

105. Mazzini L, Ferrero I, Luparello V, et al. Mesenchymal stem cell transplantation in amyotrophic lateral sclerosis: a phase I clinical trial. Exp Neurol. 2010;223(1):229-237.

106. Mazzini L, Gelati M, Profico DC, et al. Human neural stem cell transplantation in ALS: initial results from a phase I trial. J Transl Med. 2015;13:17.

107. Seledtsova GV, Rabinovich SS, Belogorodtsev SN, Parlyuk OV, Seledtsov VI, Kozlov VA. Delayed results of transplantation of fetal neurogenic tissue in patients with consequences of spinal cord trauma. Bull Exp Biol Med. 2010;149(4):530-533.

108. Chinese Branch of International Association of Neurrestoratology \& Preparatory Committee of Chinese Association of Neurrestoratology. Chinese clinical standard of neurorestorative cell therapy (2011 first vision). Chin J Clin Phys. 2011;5(19):5710-5714.

109. Chinese Branch of the International Association of Neurorestoratology; Preparatory Committee of Chinese Association of Neurorestoratology. Standard recommendation for the application of Chinese clinical cell therapy for neurorestoration. Cell Transplant. 2013;22(S1):S5-S10.

110. Chinese Association of Neurorestoratology \& Chinese Branch of International Association of Neurrestoratology. Clinical application guideline of neurorestorative cell therapy in China (2016 version). Chin J Cell Stem Cell. 2016;6:1-7.

111. Gobbel GT, Kondziolka D, Fellows-Mayle W, Uram M. Cellular transplantation for the nervous system: impact of time after preparation on cell viability and survival. J Neurosurg. 2010;113(3):666-672.

112. Savitz SI, Dinsmore J, Wu J, Henderson GV, Stieg P, Caplan LR. Neurotransplantation of fetal porcine cells in patients with basal ganglia infarcts: a preliminary safety and feasibility study. Cerebrovasc Dis. 2005;20(2):101-107. 
113. Nelson PT, Kondziolka D, Wechsler L, et al. Clonal human (hNT) neuron grafts for stroke therapy: neuropathology in a patient 27 months after implantation. Am J Pathol. 2002;160(4):1201-1206.

114. Huang H, Chen L, Xi H, et al. [Olfactory ensheathing cells transplantation for central nervous system diseases in 1,255 patients]. Zhongguo Xiu Fu Chong Jian Wai Ke Za Zhi. 2009;23(1):14-20. Chinese.

115. Lim JH, Byeon YE, Ryu HH, et al. Transplantation of canine umbilical cord blood-derived mesenchymal stem cells in experimentally induced spinal cord injured dogs. J Vet Sci. 2007;8(3):275-282.

116. Mehta T, Feroz A, Thakkar U, Vanikar A, Shah V, Trivedi H. Subarachnoid placement of stem cells in neurological disorders. Transplant Proc. 2008;40(4):1145-1147.

117. Attistella V, de Freitas GR, da Fonseca LM, et al. Safety of autologous bone marrow mononuclear cell transplantation in patients with nonacute ischemic stroke. Regen Med. 2011;6(1):45-52.

118. Friedrich MA, Martins MP, Araujo MD, et al. Intra-arterial infusion of autologous bone marrow mononuclear cells in patients with moderate to severe middle cerebral artery acute ischemic stroke. Cell Transplant. 2012;21(suppl 1):S13-S21.

119. Moviglia GA, Fernandez Vina R, Brizuela JA, et al. Combined protocol of cell therapy for chronic spinal cord injury. Report on the electrical and functional recovery of two patients. Cytotherapy. 2006;8(3):202-209.

120. Lee JS, Hong JM, Moon GJ, et al. A long-term follow-up study of intravenous autologous mesenchymal stem cell transplantation in patients with ischemic stroke. Stem Cells. 2010;28(6):1099-1106.

121. Bang OY, Lee JS, Lee PH, Lee G. Autologous mesenchymal stem cell transplantation in stroke patients. Ann Neurol. 2005;57(6):874-882.

122. Lin C, Huang HY, Zhao J, et al. Electromyogram evaluation in 389 patients with amyotrophic lateral sclerosis following olfactory ensheathing cell intracranial transplantation. J Clin Rehabil Tissue Eng Res. 2008;12(43):8422-8425.

123. Luan Z, Liu WP, Qu SQ, et al. [Treatment of newborns with severe injured brain with transplantation of human neural precursor cells]. Zhonghua Er Ke Za Zhi. 2011;49(6):445-449. Chinese.
124. Chen L,tXi H, Huang H, et al. Multiple cell transplantation based on an intraparenchymal approach for patients with chronic phase stroke. Cell Transplant. 2013;22(suppl 1):S83-S91.

125. Xi H, Chen L, Huang H, et al. Preliminary report of multiple cell therapy for patients with multiple system atrophy. Cell Transplant. 2013;22(supp11):S93-S99.

126. Chen $\mathrm{L}$, Huang $\mathrm{H}, \mathrm{Xi} \mathrm{H}$, et al. A prospective randomized doubleblind clinical trial using a combination of olfactory ensheathing cells and Schwann cells for the treatment of chronic complete spinal cord injuries. Cell Transplant. 2014;23(suppl 1):S35-S44.

127. Wang S, Cheng H, Dai G, et al. Umbilical cord mesenchymal stem cell transplantation significantly improves neurological function in patients with sequelae of traumatic brain injury. Brain Res. 2013;1532: 76-84.

128. Li JF, Zhang DJ, Geng T, et al. The potential of human umbilical cord-derived mesenchymal stem cells as a novel cellular therapy for multiple sclerosis. Cell Transplant. 2014;23(suppl 1):S113-S122.

129. Wang X, Hu H, Hua R, et al. Effect of umbilical cord mesenchymal stromal cells on motor functions of identical twins with cerebral palsy: pilot study on the correlation of efficacy and hereditary factors. Cytotherapy. 2015;17(2):224-231.

130. Li P, Cui K, Zhang B, et al. Transplantation of human umbilical cord-derived mesenchymal stems cells for the treatment of Becker muscular dystrophy in affected pedigree members. Int J Mol Med. 2015;35(4):1051-1057.

131. Chen L, Chen D, Xi H, et al. Olfactory ensheathing cell neurorestorotherapy for amyotrophic lateral sclerosis patients: benefits from multiple transplantations. Cell Transplant. 2012;21(suppl 1):S65-S77.

132. Li Y, Chen L, Zhao Y, et al. Intracranial transplant of olfactory ensheathing cells can protect both upper and lower motor neurons in amyotrophic lateral sclerosis. Cell Transplant. 2013;22(suppl 1): S51-S65.

133. Huang H, Raisman G, Sanberg PR, Sharma H, Chen L. Neurorestoratology. New York: Nova Biomedical; 2015:93-102.

134. Huang H. CNS Neurorestoratology. Beijing: Science Press; 2009
Journal of Neurorestoratology

\section{Publish your work in this journal}

The Journal of Neurorestoratology is an international, peer-reviewed, open access online journal publishing original research and review articles on the subject of Neurorestoratology. To provide complete coverage of this revolutionary field the Journal of Neurorestoratology will report on relevant experimental research, technological advances,

\section{Dovepress}

and clinical achievements. The manuscript management system is completely online and includes a very quick and fair peer-review system, which is all easy to use. Visit http://www.dovepress.com/testimonials. php to read real quotes from published authors. 